\title{
Upaya Mendorong Kolaborasi Menuju Pengembangan Struktur Ruang Bernuansa Knowledge Based di Era Disrupsi
}

\author{
Encourage Collaboration Towards the Development of Knowledge \\ Based Spatial Structure in The Disruption Era
}

\author{
Ridwan Sutriadi ${ }^{1}$, Ahmad Zaini Miftah²
}

Diterima: 17 April 2020

Disetujui: 2 Juli 2020

\begin{abstract}
Abstrak: Tulisan ini mengupas perkembangan struktur ruang kota banyak pusat, sebagai pengembangan dari tiga model struktur ruang kota klasik, yaitu monocentric, sectoral, dan multiple nuclei. Melalui studi literatur atas kajian-kajian perkembangan struktur ruang kota di luar negeri yang dimulai dari tahun 1960an sampai dengan era tahun 2000an diharapkan Indonesia dapat mengambil pelajaran akan arah pengembangan struktur ruang kota-kotanya. Pemikiran akan pengembangan struktur ruang kota dimulai dari kesadaran akan makin meluasnya ruang kota melewati batas administrasinya di era tahun 1960an (urban field), pentingnya konteks kesisteman dalam pengembangan struktur ruang kota (era 1970an), konsep kesisteman tadi harus diperjelas dengan kerjasama saling mengisi antar fungsi kota dalam konsep jejaring antar kota (era 1980an), penanganan secara terintegrasi antara kota inti dan kawasan pinggiran yang menjadi Kawasan perkotaan (era 1990an). Pada era 2000an, perkembangan polisentrik dapat terletak pada satu Kawasan perkotaan ataupun antar Kawasan perkotaan, juga mengentalnya nuansa inovasi sebagai cerminan pemanfaatan pengetahuan bagi pusat-pusat kota (era 2010an). Akhirnya, pusat kota jamak bertambah atributnya per dekade, tidak hanya cerminan minat dan kepentingan warganya dalam fungsi-fungsi kota, tetapi inovasi menerus dari penerapan pengetahuan yang dapat mengganggu pasar dan nilai eksisting (era disrupsi), sehingga diperlukan kolaborasi antar pusat untuk menciptakan sinergi struktur ruang kota.
\end{abstract}

Kata Kunci: polycentric urban region, perencanaan tata ruang, kolaborasi, disrupsi, knowledge based

\begin{abstract}
This paper explores the development of multi centre urban spatial structures, as the development of three classical models, namely monocentric, sectoral, and multiple nuclei. By implementing a literature study method on studies of the global development of urban spatial structures which began from the 1960s until the 2000s era, lessons learned for Indonesia can be taken in promoting sustainable urban spatial structure. The thought of developing urban spatial structure starts from the awareness of urban expansion beyond its administrative boundaries in the 1960s (urban field), the importance of the systemic context in the development of urban spatial structures (1970s), the systemic concept must be supported by the collaboration of mutual cooperation among city's functions in the concept of inter-city networks (1980s), spatial planning integration between core cities and suburbs which emerge urban areas (1990s). In 2000s era, the development of polycentric could be located in one urban area or among urban areas, also highly connected with innovation as a reflection of the use of knowledge for urban centers (2010s era). During the decades, it can be concluded that multi city centers lead to the enrichment of urban function in the sense of public interest and common concern, especially symbolizes continuing knowledge based innovation which could interfere market and existing values (disruption era), so collaboration among city centers is needed to perform a sustainable synergic urban spatial structure.
\end{abstract}

Keywords: polycentric urban region, spatial planning, collaboration, disruptive, knowledge-based.

\footnotetext{
${ }^{1}$ Program Studi Perencanaan Wilayah dan Kota, Sekolah Arsitektur, Perencanaan dan Pengembangan Kebijakan, Institut Teknologi Bandung

${ }^{2}$ Program Studi Administrasi Publik, Universitas Muhammadiyah Bandung
} 


\section{PENDAHULUAN}

Tulisan ini merupakan refleksi tentang perkembangan struktur ruang kota sebagai konsekuensi dari makin tingginya urbanisasi di Indonesia serta kebutuhan perencanaan tata ruang dengan gaya perencanaan di era milenial, dimana perkembangan perencanaan tidak dapat dipisahkan dari pemikiran perencanaan yang dinamis dan menerus akan konsepkonsep baru dengan tanpa melupakan konsep klasik dan konteks identitas bangsa Indonesia. Tulisan ini lebih menekankan kepada kajian literatur yang sebagian pernah dikompilasikan oleh penulis yang memiliki petajalan penelitian berupa kota komunikatif menuju suatu kota yang berpengetahuan. Kajian literatur disini meliputi makalah kajian literatur tentang struktur ruang kota polisentrik serta buku-buku yang pernah ditulis oleh penulis, ditambah dengan acuan-acuan lainnya yang berkaitan dengan kota berbasis pengetahuan.

Menjadi menarik untuk membahas struktur ruang di era disrupsi seperti sekarang ini, inovasi akan senantiasa diperlukan guna membuat perencanaan yang lebih tanggap terhadap pembangunan berkelanjutan dan berwawasan lingkungan di satu sisi, serta di sisi lainnya terdapat peran peningkatan kompetensi sumberdaya manusia dalam bentuk pengembangan ilmu pengetahuan secara menerus guna mengoptimalkan daya saing kawasan. Pusat-pusat pertumbuhan yang digerakan oleh industri-industri sebagaimana diuraikan pada teori-teori klasik sudah mulai harus bergeser di era disrupsi, sebut saja salah satunya karena adanya pemetaan ataupun dampak disrupsi atas geografis sebagaimana dijelaskan oleh Tan Yigitcanlar dan Tommi Inkinen dalam buku terbarunya Geographies of Distruption. Place Making for Innovation in the Age of Knowledge Economy (Yigitcanlar \& Inkinen, 2019).

Sebagai upaya identifikasi, kemudian analisis, dan akhirnya membuat formulasi perencanaan, khususnya dalam perencanaan kota, para planolog atau perencana berupaya mengidentifikasinya melalui pemahaman akan struktur ruang kota. berikut ini uraian tentang tiga model struktur ruang klasik sebagaimana diterangkan dalam buku yang berjudul Land and the City oleh Kivell (1993). Secara klasik, struktur ruang kota pertama kali ialah struktur ruang kota concentric, dikembangkan oleh sosiolog E.W. Burgess (1925) berdasarkan pengamatan empiris di Chicago (Kivell, 1993). Kemudian ada struktur ruang sectoral yang dikembangkan oleh $\mathrm{H}$. Hoyt (1939) dengan mempertimbangkan tingkat sewa perumahan pada kota-kota di Amerika Serikat termasuk Chicago. Model Hoyt dapat dianggap sebagai pengembangan dari model Burgess karena telah mempertimbangkan arah pertumbuhan kota dan jarak dari pusat kota yang kemudian menentukan ragam guna lahan. Hoyt mengembangkan modelnya dengan memberikan penekanan bahwa hunian penduduk berpengasilan tinggi terpisah dari hunian penduduk berpenghasilan rendah juga industri dengan adanya Kawasan penyangga dari hunian penduduk berpenghasilan menengah.

Dalam hal ini, pendekatan Burgess lebih menekankan kepada faktor sosial, daya saing ekologis, dan migrasi, sementara itu Hoyt lebih menekankan kepada nilai kenyamanan berikut filter/penyangga antar guna lahannya. Pelajaran yang dapat diambil dari kedua pendekatan ini ialah bahwa untuk kondisi saat ini, CBD (central business district) bukan selamanya merupakan fokus aktivitas komersial dari suatu kota, karena berkaitan dengan sektor-sektor utama dari suatu kota yang pengembangan pusat-pusat komersial tadi sangat dipengaruhi oleh jaringan dan moda transportasi dari suatu kota.

Struktur ruang klasik yang ketiga ialah multiple nuclei yang dikembangkan oleh Harris dan Ullman (1945). Model ini dapat dianggap sebagai suatu model evolusi dari yang sebelumnya karena memperkenalkan bahwa suatu kota dapat memiliki pusat lebih dari satu sebagai ciri dari makin berkembangnya spesialisasi dari suatu kota yang didukung melalui struktur seluler, sehingga memungkinkan munculnya pusat pertumbuhan lain selain pusat kota, biasanya terdapat di Kawasan pinggiran (seperti pusat perbelanjaan skala regional), ataupun kawasan industri, atau permukiman mewah di kawasan pinggiran.

Model multiple nuclei ini mulai mempertimbangkan tentang interaksi dari faktor-faktor lokasional, diantaranya ialah: Pertama, ada pertimbangan kondisi topografis dan historis sebagai bagian tidak terpisahkan bagi pertumbuhan dan perkembangan kota ke depan. 
Kedua, mempertimbangkan adanya perbedaan tingkatan dari aktivitas retail yang tidak selalu mencari lokasi di pusat kota utama, melainkan ada saatnya lebih memilih lokasi di kawasan pinggiran yang mendekati pasar. Ketiga, memungkinkan terjadinya aglomerasi ekonomi dengan eksternalitasnya yang menyebabkan beberapa aktivitas mengelompok secara bersama.

Peran para perencana dalam menyikapi tiga model klasik struktur ruang kota ini telah pula disampaikan oleh Kivell (1993) dengan menjelaskan bahwa penting para perencana untuk memformulasikan intervensi dalam melindungi kepentingan publik sebagai tanggapan atas ketidakberhasilan penataan ruang kota, seperti adanya kenyataan bahwa:

1. Pasar lahan lebih bersifat tidak terduga dan berpotensi menimbulkan bencana, padahal lahan dapat digunakan secara lebih optimal dan berkelanjutan.

2. Pasar lahan lebih menekankan kepada mekanisme harga, dimana pelaksanaannya harus dipertimbangkan kembali menurut tingkat kemanfaatannya secara publik, dimana lahan dapat memiliki fungsi sosial seperti sekolah, rumah sakit, atau taman.

3. Terdapat peluang penguasaan lahan berikut skema pembiayaannya yang memungkinkan dominasi atas kelompok lemah.

4. Pasar tidak terlalu memperhatikan akan eksternalitas negatif seperti kemacetan, kebisingan ataupun kehadiran industri dengan berbagai dampak (negatif)nya.

Pendahuluan tentang model struktur ruang kota klasik di atas, akan dilanjutkan dengan kajian literatur tentang pengembangan struktur ruang klasik tadi ditambah dengan bahasan atas pembangunan kota berbasis pengetahuan. Tetapi sebelumnya perlu dijelaskan bahwa perhatian para akademisi dan peneliti akan perkembangan model struktur ruang tersebut dimulai pada tahun 1960an dengan makin meluasnya kawasan perkotaan sampai kepada kawasan pinggiran, dan kemudian terjadinya fenomena suburbanisasi di kawasan pinggiran. Senada dengan uraian kesimpulan Kivell di atas yang menekankan kepada nilai dan harga lahan berikut aktivitasnya sebagai konsekuensi dari makin padatnya penduduk di perkotaan, para pakar ekonomi merupakan pihak yang sejak awal menstudi secara spesifik tentang pergeseran struktur ruang kota ini (Harrison Jr \& Kain, 1974), dan mereka lebih tertarik mendalami sisi fungsi kepadatan dari aktivitas berbasis tempat tinggal dan tempat kerja, sebagai kelanjutan kajian sebelumnya atas fenomena aktivitas optimal di pusat kota dan di luar pusat kota berikut komponen jarak dari pusat ke kawasan pinggiran kota. oleh sebab itu, sejak tahun 1960an ditandai dengan tulisan tentang urban field oleh Friedmann \& Miller (1965), ditegaskan oleh Edwin S. Mills (Mills, 1970) yang mengutarakan formulasi tentang fungsi kepadatan perkotaan. Sepuluh tahun kemudian Mills bersama Tan kembali melakukan riset fungsi kepadatan antara kota di negara maju dengan kota di negara berkembang (Mills \& Tan, 1980), meskipun bila ini dilaksanakan untuk konteks kota-kota di Indonesia masih akan kesulitan karena keterbatasan data. Oleh sebab itu, penting bagi kotakota di Indonesia untuk lebih memahami terlebih dahulu tentang kerangka besar pergeseran model struktur ruang kota klasik yang kemudian berkembang menjadi struktur ruang polisentrik guna memahami ide utama dan kemudian pendekatan yang cocok untuk meneliti kota-kota di Indonesia.

Sebagai tambahan, demikian menariknya studi tentang struktur ruang kota pernah disampaikan oleh Giuliano yang studi doktoralnya di bidang sosial, tetapi karena kesehariannya sebagai Professor di University of Southern California menghadapi fenomena perkembangan struktur ruang kota ini, menjadi tertarik untuk mendalami studi-studi yang memberikan pengayaan atas struktur ruang kota dimulai di tahun 1990an, terutama dari sisi hubungan transportasi guna lahan dan struktur ruang metropolitan yang pernah distudinya melalui perjalanan bekerja sebagai pembentuk struktur ruang kota (Giuliano \& Small, 1993), sampai dampak teknologi informasi dan komunikasi atas struktur ruang kota metropolitan (Giuliano, 1998), dan terkhir mendalami manajemen angkutan kota di wilayah metropolitan (Giuliano, Kang, \& Yuan, 2018). Studi-studi Giuliano tersebut turut mengilhami studi-studi polisentrik di wilayah metropolitan Indonesia dengan pendekatan dari sisi pergerakan ke 
fasilitas pelayanan (Sutriadi, 1996), dan pergerakan ke tempat kerja (Kombaitan, 1998), juga metode yang sama tentang dampak teknologi informasi dan komunikasi atas struktur ruang kota metropolitan dari sisi para pekerja yang tidak memiliki keterikatan kuat terhadap lokasi tempat kerja untuk kasus pinggiran Kota Bandung (Nurfalah, 2008; Nurfalah \& Sutriadi, 2009). Berdasarkan studi-studi terkait penelusuran pusat kota polisentrik tersebut, menjadi penting untuk memberikan gambaran teoritik secara kronologis dari perkembangan struktur ruang kota satu pusat yang mulai berganti menuju kota banyak pusat karena pendekatan kota satu pusat atau monosentrik sudah tidak dapat menerangkan fenomena berkembangnya perkotaan baik di negara maju maupun negara berkembang. Selain itu, belajar dari kotakota di Eropah, maka pergeseran dari kota monosentrik ke kota polisentrik inter region atau sistem kota antar negara, membutuhkan suatu proses dan penyesuaian yang relatif lama, hal ini pula yang perlu dipahami dalam konteks perencanaan kota-kota dalam konteks struktur ruang kota baik dalam suatu wilayah ataupun lintas wilayah di Indonesia.

\section{METODE}

Artikel ini menggunakan kajian literatur yang berupaya untuk memberikan gambaran tentang pentingnya pemahaman akan teori struktur ruang kota yang senantiasa berkembang seiring dengan meningkatnya penduduk dan aktivitas yang berkembang di perkotaan. Mulai dari pertumbuhan penduduk yang diiringi dengan pemanfaatan lahan secara horizontal dari pusat ke kawasan pinggiran sampai kepada munculnya fenomena baru tentang kreasi ataupun ide merencana kota yang didasari oleh pengembangan ilmu pengetahuan sebagai basis pembangunan sekaligus menanggapi persoalan-persoalan terkini perkotaan pada era abad ke-21 ini. Bahan tulisan ini bersumber dari jurnal, buku teks, serta buku-buku yang pernah diterbitkan oleh penulis sebelumnya, seperti perspektif perencana tentang smart city (Sutriadi, 2015), serta makalah kajian literatur tentang struktur kota polisentrik (Sutriadi, 2004).

\section{HASIL DAN PEMBAHASAN}

\section{Fenomena Disrupsi}

Istilah disrupsi atau dari ungkapan aslinya disruptive innovation diperkenalkan oleh Joseph L. Bower dan Clayton M. Christensen dalam artikel di Harvard Business Review terbitan Januari-Februari tahun 1995. Berdasarkan artikel tersebut, secara sederhana disruptive innovation yang berkonteks bisnis ini dapat diartikan sebagai suatu inovasi dengan fokus menciptakan pasar baru dan jaringan nilai, dimana hal ini akan menggangu pasar dan jaringan nilai yang telah ada sebelumnya, sehingga inovasi seperti ini dapat menggantikan perusahaan, produk, bahkan alliansi terkemuka terutama pada tataran global (Sutriadi, 2018). Pelajaran yang dapat diambil bagi perencana ialah bahwa dengan adanya fenomena disrupsi ini ialah bahwa penataan ruang dimana di dalamnya terdapat formulasi konsep struktur ruang, sudah saatnya memahami fenomena disrupsi dikaitkan dengan ruang, supaya inovasi ataupun perubahan yang dilakukan oleh pemangku kepentingan akan lebih dapat diantisipasi dalam konteks ruang.

\section{Struktur Ruang Kota Polisentrik}

Polisentris, secara sederhana, dapat didefiniskan sebagai multi-pusat dalam suatu kawasan perkotaan (Kloosterman \& Musterd, 2001). Kemunculan model struktur ruang polisentris ini akibat dari ketidaksanggupan teori struktur kota monosentris untuk menerangkan perkembangan tata ruang kota-kota modern saat ini yang sudah tumbuh ke arah kota 'multi-pusat' (Berry \& Kim, 1993; Richardson, 1988).

Awal kemunculan model struktur kota polisentris terjadi pada era tahun 1960an yang di antaranya dipelopori oleh Friedmann \& Miller (1965) yang memperkenalkan konsep 
'urban field'. Model polisentris pada dasawarsa ini lebih pada penggambaran fenomena multi-pusat dalam konteks suatu kota. Pada era tahun 1970-an, model struktur kota polisentris sudah mengalami pengembangan dan mulai mencoba menggambarkan fenomena multi-pusat dalam konteks yang lebih luas (antar kota-kota) seperti yang dikemukakan oleh Pred (1977) dengan konsep 'city systems'-nya, sebagai upaya untuk menjawab kritikan terhadap konsep urban field yang hanya menggambarkan fenomena multipusat dalam konteks suatu kota. Namun demikian, konsep 'city systems' ini tetap belum dapat mengemukakan kompleksitas sosial-ekonomi dari wilayah perkotaan secara lengkap (Heikkila, 1992). Sejalan dengan proses penggambungan Eropa pada era tahun 1980-an muncul konsep 'urban networks', yang menggambarkan keterkaitan antar kota-kota industri di Eropa. Selanjutnya, pada era tahun 1990-an muncul dua konsep dalam menggambarkan fenomena muti-pusat, yaitu konsep 'edge city' yang dikemukakan oleh Garreau (1991) dan konsep 'polycentric urban region' yang menekankan pada keterkaitan aktivitas ekonomi dalam skala antar kota sebagai fokus kajian dalam menggambarkan struktur kota polisentris. Para pakar yang mengungkapkan konsep 'polycentric urban region' pada era tahun 1990-an di antaranya adalah Clark \& Kuijpers-Linde (1994); Priemus (1994); Batten (1995); Albrechts (1998); Lambooy (1998); dan Dieleman \& Faludi (1998). Sedangkan pada awal tahun 2000an perkembangan konsep polisentris tidak terlepas dari kajian terhadap konsep 'polycentric urban region'. Kloosterman \& Musterd (2001) - salah satu pakar dan peneliti yang turut mewarnai perkembangan konsep polisentris pada awal tahun 2000-an ini - mencoba mengidentifikasi karakteristik struktur polisentris dari sisi intraurban dan interurban.

Dalam perkembangannya, penggambaran struktur ruang kota dengan menggunakan konsep polisentris dilakukan oleh para pakar dan peneliti dengan persepsi yang berbeda-beda berdasarkan latar belakang bidang keilmuannya (seperti: perencana, ahli geografi, ahli demografi, ahli ekonomi, ahli sosial, dan sebagainya). Hal ini terjadi karena kota sebagai obyek kajiannya terdiri atas berbagai aspek yang kompleks, seperti aspek spasial, ekonomi, sosial, demografi, dan sebagainya. Merujuk kepada tulisan Kloosterman \& Musterd (2001), dalam memahami karakteristik intraurban polisentris dapat dikelompokkan ke dalam empat dimensi, yaitu bentuk fisik (physical form), kesatuan politik (political entity), hubungan fungsional (functional relationships), serta hubungan identitas dan representasi wilayah (relates to identity and the representation of the region).

1. Bentuk Fisik

Terjadinya proses suburbanisasi dalam perkembangan kota mengindikasikan timbulnya fenomena 'cross-commuting' Clark \& Kuijpers-Linde (1994), yaitu pola komuting yang terjadi tidak hanya dari suburban ke pusat kota tetapi juga terjadi sebaliknya dari pusat kota ke suburban atau antar pusat pada suburban. Pola komuting yang terjadi bisa saja berbentuk radial atau linier bergantung pada sejarah terbentuknya kota tersebut. Moda transportasi yang digunakan komuter pada intraurban polisentris didominasi oleh moda transportasi umum (public transport) (Kloosterman \& Musterd, 2001). Karena mempunyai skala ruang yang kecil, maka dalam pengembangan intraurban polisentris sangat perlu menjaga dan melestarikan ruang terbuka hijau (open space) dan keanekaragaman hayati (biodiversity) yang terdapat di dalamnya (lihat Beatley, 2000)

2. Kesatuan Politik

Pengembangan intraurban polisentris dapat dilakukan melalui kebijakan yang dikeluarkan oleh satu pemerintah (kota) saja (Kloosterman \& Musterd, 2001). Karena biasanya secara administratif (kesatuan politik), intraurban polisentris (baik pusat kota maupun suburban-nya) berada dalam satu wilayah administrasi kota. Hal ini tentunya akan memudahkan dalam perencanaan, pelaksanaan, dan pengendalian pengembangan intraurban polisentris tersebut.

3. Hubungan Fungsional

Skala ruang yang kecil yang berimplikasi pada pendeknya jarak antar pusat pada intraurban polisentris membuat hubungan fungsional antar pusat tersebut menjadi sangat 
kuat. Sehingga dalam konteks intraurban polisentris sangat memungkinkan dilakukan pembagian tempat bekerja dengan mengembangkan lokasi baru pada salah satu pusatnya tanpa perlu memperhatikan fungsi yang diemban sebelumnya (Kloosterman \& Musterd, 2001).

4. Hubungan Identitas dan Representasi Wilayah

Identitas intraurban polisentris sangat terkait dengan sejarah pembentukan kotanya dan cenderung mempunyai representasi simbolis yang kuat, misalnya berupa architectural landmark, tokoh terkenal, budaya, dan sebagainya (Kloosterman \& Musterd, 2001). Hal senada juga dikemukakan oleh Anderson (1983) yang mengatakan: "Cities, even polycentric cities, can still be seen as imagined communities". Pengembangan intraurban polisentris biasanya tidak akan mengubah identitas yang disandangnya.

Berdasarkan uraian di atas, terdapat beberapa hal yang dapat diambil dari perkembangan teori struktur kota tersebut (Sutriadi, 2015) khususnya terkait dengan kesadaran perlunya inovasi dengan dukungan teknologi guna mewujudkan wilayah dan kota berkelanjutan ialah:

\section{Pelajaran Dari Perkembangan Struktur Kota Era 1960-An}

Deliniasi wilayah perkotaan yang merupakan cerminan dari kebutuhan kota tersebut pada masa mendatang. Pada dasarnya ketika suatu kota direncanakan, sudah selayaknya direncanakan secara lengkap mulai dari deliniasi fisik ketika pertama direncanakan, untuk menampung berapa penduduk dan keragaman lapangan kerja apa saja yang akan disediakan juga infrastruktur pendukungnya, termasuk pula akan direncanakan sebagai kota dengan karakteristik seperti bagaimana corak penataannya tidak hanya pada tataran lokal tetapi global (memformulasikan pada skala global). Hal yang seringkali dilupakan untuk konteks kota ialah bahwa suatu kota dapat dengan mudah bertransformasi dari kota desa menjadi kota kecil, kota menengah, dan berikutnya menjadi kota besar dan metropolitan. Padahal penataan dapat dilakukan dengan tetap menjaga fungsi dan peran kota sebagai kota desa ataupun kota kecil ataupun menengah, tidak selalu harus menjadi kota besar bahkan metropolitan. Makna penting tentang deliniasi wilayah perkotaan tersebut dibahas mengingat pada era tahun 1960an sudah mulai ada fenomena terbentuknya kota-kota yang melewati batas administrasinya menuju suatu kota metropolitan (Friedmann \& Miller, 1965).

\section{Pelajaran dari perkembangan struktur kota era 1970-an}

Pada era ini struktur kota sudah mulai memperhitungkan tentang adanya fungsi dalam konteks kesisteman pada tataran regional dan kemudian pada tataran global. Suatu kota selayaknya direncanakan untuk memiliki fungsi spesifik yang dapat melengkapi (prinsip complementarity) ataupun memberikan alternatif layanan tertentu dibandingkan dengan kota lainnya (prinsip substitutory), juga selayaknya memiliki tingkat akses yang tinggi tidak hanya bertopang kepada akses infrastruktur fisik tetapi mulai memikirkan infrastruktur digital/virtual (prinsip transfer ability dan intervening opportunity) supaya barang dan jasa dapat secara fisik ataupun virtual dikirim ataupun diterima oleh kota tersebut. Pada era tahun 1970an ini, dengan dilandasi bahwa masing-masing kota memiliki basis ekonomi dan membutuhkan interaksi antara satu dengan yang lainnya, Pred memperkenalkan konsep tentang sistem kota guna menggambarkan keterkaitan secara ekonomi antara kota yang satu dengan kota lainnya di dalam suatu negeri atau suatu wilayah. Pred membuat suatu perbedaan secara lengkap antara keterkaitan (interdependence) antar kota dalam suatu negara atu wilayah dan keterbukaan (openness) dari kumpulan kota-kota. Indikator yang digunakan oleh Pred yang kemudian menjadi sangat penting di era digital, ialah aliran informasi yang bersifat khusus, misalnya informasi yang digunakan pembuat keputusan di dalam suatu wilayah (Pred, 1977). 


\section{Pelajaran dari perkembangan struktur kota era 1980-an}

Kota selayaknya memiliki jejaring sinergis dengan kota ataupun kawasan non perkotaan lainnya pada tataran regional ataupun global dengan tetap berupaya menciptakan daya saing melalui penelitian mendalam tentang kekhasan lokal yang dimiliki ataupun kekhasan lokal yang selayaknya diciptakan supaya berdaya saing dengan mengutamakan sumberdaya alam dan manusia setempat.

Memasuki era 1980an, struktur ruang kota memasuki suatu transformasi baru yang tidak terlepas dari fenomena perubahan politik global seperti adanya reunifikasi Jerman dan proses penggabungan Eropa. Pada era ini muncullah konsep 'urban networks, yang menggambarkan keterkaitan antar kota-kota industri di Eropa. Beberapa dokumen penelitian dan politik pada waktu itu menekankan bahwa penggabungan Eropa telah menjadi pendorong pertumbuhan terbentuknya jaringan antar kota-kota di Eropa. Kerjasama dan sharing aset-aset komplementer menandai pertumbuhan urban networks, yang sering disebut sebagai 'innovative class', yang terjadi secara paralel dengan pertumbuhan jaringan bisnis. Faktor utama dari innovative class ini adalah ketersediaan sumberdaya manusia 'trans-nasional', serta jaringan transportasi dan infrastruktur komunikasi yang baik (Houtum dan Lagendijk, 2001). Pada perkembangan selanjutnya, istilah innovative class akan menjadi bagian dari munculnya keragaman tema pembangunan kota, khususnya kota kreatif.

Pengembangan konsep urban networks itu sendiri telah menjadi konsep yang penting dalam penggambaran struktur kota polisentris, terutama dalam penggambaran peningkatan keterkaitan antar elemen jaringannya. Namun demikian, konsep ini pun belum dapat menggambarkan secara jelas tipologi dari konfigurasi kota-kota tersebut (Camagni \& Salone, 1993).

\section{Pelajaran dari perkembangan struktur kota era 1990-an}

Awal era 1990an ditandai dengan berkembangnya suatu fenomena yang merupakan tahapan lanjutan dari urban field di era 1960an, yaitu dengan kemunculan istilah 'edge city', sebagaimana disampaikan oleh Garreau dalam bukunya (Garreau, 1991). Konsep edge city ini menerangkan bahwa proses suburbanisasi yang terjadi pada perkembangan kota telah menimbulkan tumbuhnya kota baru yang berjarak beberapa mil dari kota yang lama. Kota baru ini mempunyai karakteristik yang berbeda dengan suburban tradisional karena di kota baru ini terjadi aktivitas perkotaan. Sementara itu, Marcuse (1998) beberapa edge city telah berkembang menjadi 'total urban' baik dari sisi gaya hidup maupun dari sisi aktivitasnya, dimana di dalamnya akan terdapat aktivitas bisnis, pusat kerja dan komersial, juga fasilitas budaya sebagai pelengkap dari perumahan-perumahan yang telah dibangun. Ilustrasi tentang fenomena ini seringkali mengambil contoh Phoenix, Arizona yang ditunjukan pada film dokumenter kemunculan dan pertumbuhan kotanya.

Pada era tahun 1990an inilah istilah polisentrik dikenal pada wacana struktur ruang kota, guna menggambarkan struktur kota dalam skala ruang satu kota dan kawasan pinggirannya. Istilah ini sudah mulai banyak digunakan oleh para pakar dan peneliti untuk menggambarkan struktur ruang perkotaan dalam skala ruang yang lebih luas (antar kotakota), yang diungkapkan dalam konsep 'polycentric urban region'. Konsep ini telah dijadikan sebagai alat analisis dalam perencanaan tata ruang kota di Eropa (Bailey \& Turok, 2001). Sebagai pengembangan konsepnya, dapat pula dikatakan bahwa skala yang menjadi fokus kajian dari polycentric urban region adalah intermetropolitan (Dieleman \& Faludi, 1998).

Suatu polycentric urban region dapat didefinisikan sebagai suatu wilayah yang mempunyai dua atau lebih kota yang berdiri sendiri dan mempunyai keterkaitan aktivitas ekonomi satu sama lain tanpa ada yang menjadi pusat dominan, dengan jarak antar pusat kotanya cukup dekat. Batas jarak maksimum antar pusat kota dalam suatu polycentric urban area adalah dapat ditempuh dalam waktu tidak lebih dari satu jam perjalanan (Batten, 1995). 
Tetapi, batasan Batten ini dinilai terlalu sederhana dan kurang memenuhi syarat, karena di wilayah Eropa Barat bagian utara terdapat kota-kota yang mempunyai keterkaitan aktivitas ekonomi tetapi satu sama lain mempunyai jarak yang ditempuh lebih dari satu jam waktu perjalanan (Bailey \& Turok, 2001).

Terbentuknya suatu polycentric urban region, menurut beberapa pakar dan peneliti, adalah karena kota-kota dalam wilayah tersebut satu sama lain mempunyai keterkaitan aktivitas ekonomi (kelanjutan ataupun fase dari dekade struktur kota sebelumnya). Bentuk keterkaitan aktivitas ekonomi yang dimaksud antara lain berupa: pemanfaatan aset-aset perekonomian secara bersama-sama, seperti keterkaitan terhadap penggunaan dan pemanfaatan pelabuhan atau bandar udara yang sama (Priemus, 1994), ataupun adanya fasilitas pendidikan tinggi yang berkualitas sehingga membuka peluang untuk dimanfaatkan bersama oleh penduduk dari kota-kota tersebut (Lambooy, 1998). Bentuk keterkaitan lainnya adalah terbentuknya jaringan bisnis antar perusahaan di antara kota-kota tersebut sebagai akibat perkembangan inovasi ekonomi (Albrechts, 1998; Batten, 1995). Terdistribusinya populasi penduduk dan tempat bekerja di antara kota-kota dalam wilayah tersebut yang menyebabkan timbulnya fenomena 'cross-commuting', juga merupakan bentuk keterkaitan aktivitas ekonomi dalam suatu polycentric urban region (Clark \& Kuijpers-Linde, 1994). Dimana fenomena commuting ini akan turut mewarnai pula struktur ruang kota dewasa ini karena berkembang seiring dengan penguasaan teknologi transportasi serta teknologi informasi dan komunikasi (TIK).

Konsep polycentric urban region pada era tahun 1990an, yang menekankan keterkaitan aktivitas ekonomi sebagai fokus kajian dalam penggambaran perkembangan ruang kota polisentris, dalam perkembangannya mendapat beberapa kritikan. Berdasarkan dimensi keruangan, konsep ini belum bisa menjelaskan secara lengkap tentang batas spasial dari suatu policentric urban region. Begitu pula dengan penggunaan argumen-argumen ekonomi dalam konsep ini akan menyulitkan pengaplikasiannya ke dalam bentuk fisik ruang. Kritikan lainnya adalah konsep ini hanya memandang kota-kota di dalam suatu polycentric urban region mempunyai kedudukan yang sama (tidak ada yang menjadi pusat dominan) sehingga keterkaitannya merupakan keterkaitan 'horizontal', padahal faktanya terdapat pula kotakota yang mempunyai keterkaitan 'vertikal' karena ada yang menjadi pusat dominan (Bailey \& Turok, 2001).

Dari perkembangan struktur ruang kota di era 1990an, tertunjukan bahwa kota selayaknya memiliki karakteristik spesifik sebagai basis untuk meningkatkan tingkat keberartian ataupun kestrategisan kota tersebut dengan kota-kota lainnya pada tataran yang lebih luas. Adapun tingkat keberartian (signifikansi) tersebut dapat dicipatkan melalui dukungan politik (ada kebijakan khusus pemerintah dalam pengembangan kawasan), ataupun keterkaitan fungsi spesifik yang dimiliki untuk ditawarkan ketika menciptakan jejaring sinergis dengan kota lainnya (penetapan ataupun penciptaan nilai kestrategisan kota), memiliki identitas khas pada tataran yang lebih luas (prinsip rare dan irreplacable) seperti memiliki kekayaan alam termasuk keanekaragaman hayati.

\section{Pelajaran dari perkembangan struktur kota era 2000-an}

Perkembangan konsep polisentris pada awal tahun 2000an tidak terlepas dari kajian, kritik, serta pengembangan terhadap konsep 'polycentric urban region'. Beberapa kajian teoritis yang turut mewarnai perkembangan konsep polisentris pada awal tahun 2000an ini antara lain adalah: Albrechts, (1998); Bailey \& Turok (2001); Beatley (2000); Champion (2001); Kloosterman \& Lambregts (2001); Kloosterman \& Musterd (2001); Musterd \& Van Zelm (2001); Van Houtum \& Legendijk (2001).

Polisentrik secara sederhana dapat didefiniskan sebagai multi-pusat dalam suatu kawasan perkotaan. Salah satu karakteristik utama dari polisentrisitas adalah adanya fenomena 'cross commuting'. Cross commuting yang terjadi hanya di wilayah suatu kota beserta suburban-nya menandakan bahwa wilayah tersebut merupakan 'a polycentric city' atau 
dengan istilah lain disebut 'intraurban polisentris'. Sedangkan cross commuting yang terjadi tidak hanya di wilayah suatu kota beserta suburban-nya tetapi mencakup wilayah yang meliputi dua atau lebih kota menandakan bahwa wilayah tersebut merupakan 'a polycentric urban region' atau dapat disebut juga sebagai 'interurban polisentris' (Kloosterman \& Musterd, 2001).

Lebih jauh lagi, Kloosterman dan Musterd mengungkapkan karakteristik dari suatu konfigurasi polycentric urban region, yaitu sebagai berikut:

1. Terdiri dari sejumlah kota-kota yang berbeda secara historis.

2. Tidak ada kota yang secara jelas mendominasi baik dalam bidang politik, ekonomi, budaya, maupun aspek lainnya (walaupun salah satu kota memiliki populasi penduduk yang lebih banyak).

3. Cenderung terdiri atas suatu kota besar dan beberapa kota kecil, yang bersama-sama mengatur dan mengelola wilayahnya untuk kepentingan ekonomi bersama.

4. Kota-kota tersebut membentuk konfigurasi polisentris dengan batasan terutama berdasarkan jarak komuting maksimum, dan biasanya terkonsentrasi di bagian tertentu dari wilayah suatu negara.

5. Kota-kota tersebut tidak hanya berbeda secara ruang tetapi juga merupakan kesatuankesatuan politik yang independen.

Konsep polycentric urban region ini telah dijadikan sebagai konsep dalam perencanaan tata ruang kota di Eropa. Keunggulan penggunaan konsep ini dalam perencanaan tata ruang salah satunya dapat dilihat dari dimensi ekonomi, yaitu suatu kumpulan kota-kota yang dikembangkan berdasarkan konsep polycentric urban region akan mempunyai daya saing ekonomi yang lebih tinggi baik secara agregat maupun masing-masing kota dibandingkan jika pengembangannya dilakukan secara separatis (lihat Bailey \& Turok, 2001).

Sementara itu, Van Houtum \& Legendijk (2001) mencoba memberikan penjelasan mengenai konsep polycentric urban region melalui uraian sebagai berikut: Pertama, konsep polycentric urban region merupakan gabungan dari konsep 'urban interdependencies' dan konsep klasik 'urban hierarchy'. Artinya, dalam suatu polycentric urban region tidak hanya memperhatikan keterkaitan kota-kota secara horizontal tetapi juga secara vertikal. Kedua, konsep polycentric urban region merupakan suatu konsep perencanaan, bukan sekedar teori atau hipotetis belaka. Oleh karena itu, konsep ini bukan merupakan 'an empirically functional logic' tetapi didasarkan pada 'images of functional integration'. Ketiga, meskipun konsep ini memberikan penekanan terhadap peran informasi, aset-aset non-tangible dan komunikasi elektronik, tetapi hubungan fungsional antar kota secara fisik tetap diperlukan karena konsep ini merupakan konsep yang dapat diaplikasikan secara ruang. Keempat, batasan 'polycentric region' dalam konsep ini tidak terbatas pada batasan teritorial (batas administrasi).

Dari uraian tentang perkembangan struktur kota di era 2000an, tertunjukan bahwa peningkatan daya saing kota selayaknya ditempatkan pada konteks pembangunan berkelanjutan bukan untuk memenuhi kebutuhan saat ini yang cepat menghasilkan (prinsip low impact development dan kebijakan untuk dalam menyikapi prinsip quick yielding). Dalam hal ini menjadi penting untuk mempertimbangkan kembali pertumbuhan dan perkembangan kota dikaitkan dengan batasan fisik, fungsional, serta kewenangan administratif (percepatan ataupun perlambatan pembangunan kota).

\section{Pelajaran dari perkembangan struktur kota era 2010-an}

Di antara tulisan yang berkaitan dengan perkembangan struktur kota di era 2010-an, terdapat tulisan menarik tentang refleksi struktur ruang di Kota Los Angeles dan sekitarnya yang ditulis oleh para peneliti di UC-Irvine, Kevin Kane, John R. Hipp dan Jae Hong Kim (Kane, Hipp, \& Kim, 2018). Mereka menjelaskan bahwa penentuan dan kemudian pertumbuhan dari pusat-pusat, tidak terlepas dari potensi kawasan tersebut berikut ekosistemnya. Mereka menjelaskan tentang pusat-pusat pertumbuhan di Kota Los Angeles yang merupakan knowledge-intensive business services dimana inovasi dan perkembangan 
teknologi informasi menjadi penentu keberhasilan dan keberlanjutannya selama tiga dekade terakhir. Mereka menjelaskan bahwa inovasi berikut ekosistem yang berhasil akan memberikan manfaat positif kepada daya tarik dan pengembangan ekonomi.

Tulisan yang lain menjelaskan bahwa pusat-pusat pertumbuhan yang dibuat secara inovatif akan menjadi makin berkembang dengan adanya penciptaan interaksi-interaksi dengan lokasi/kota/wilayah lainnya dengan bantuan teknologi-teknologi terkini (Cowell, 2010). Pembelajaran dari negara bagian California tersebut dapat memberikan pemahaman bahwa pertumbuhan dan perkembangan kota dan daya saingnya sudah selayaknya dipandang sebagai suatu ekosistem global, dimana inovasi dan kemajuan teknologi menjadi suatu tantangan dalam pengembangannya, selain dari pemahaman mendalam akan pertimbangan keterbatasan fisik alaminya yang kerap dikesampingkan guna menjadi bagian dari pusat pertumbuhan global. Berkaca dari hal tersebut, maka inovasi tetap dikembangkan guna menciptakan suatu tatanan kehidupan yang berkeadilan, memberikan kesadaran bahwa manusia hidup dengan lingkungan alami yang terbatas, serta dirangsang pula bagaimana inovasi dikembangkan supaya pembangunan berkelanjutan dapat pula seiring dengan usaha ataupun bisnis yang dilakukan.

\section{Pelajaran Dari Kehadiran Space of Flow Sebagai Fase Pertumbuhan Dan Perkembangan Kota Lanjut Dengan Dukungan TIK}

Kehadiran TIK bagi perencanaan wilayah dan kota akan memberikan dampak terhadap tiga hal utama berbasis kepada fenomena space of flow menurut Manuel Castells (2010), yaitu orientasi pergerakan orang ataupun barang karena adanya dorongan ketersediaan perangkat TIK, akan terhadap pusat-pusat pertumbuhan pada suatu kota dan di luar kawasan perkotaan yang timbul dengan dukungan dari TIK. Terakhir, akan dibutuhkannya suatu penataan ruang wilayah dan kota yang baru sebagai dampak dari adanya TIK, seperti kepada pergerakan, alihfungsi guna lahan, serta para pengambil keputusan kunci terhadap pertumbuhan dan perkembangan kota pada masa sekarang ini.

\section{Blue Banana dan Red Octopus}

Blue banana merupakan suatu istilah dalam konsep struktur ruang yang dikembangkan sejak 1989 dengan penekanan kepada basis ekonomi berdaya saing dari pusat-pusat pertumbuhan lintas negara di Eropah (London, Amsterdam, Brussels, Frankfurt, Zurich, dan Milan). Blue Banana merupakan hasil pemikiran negara-negara di Eropah yang mulai digulirkan melalui Konferensi Menteri Perencanaan Teritorial (The European Conference of Ministers of Territorial-CEMAT) tahun 1979, dimana pembangunan kawasan-kawasan (berikut pusat) metropolitan di Eropah dibangun dan dikembangkan secara terkoordinasi berdasarkan ukuran penduduk, dan kekhasan ragam pembangunan antar metropolitan tadi yang saling terhubungkan. Konsep ini kemudian disempurnakan lagi hampir satu decade kemudian (1988) dengan menambahkan atribut lima tingkatan prioritas pembangunan dalam konteks tata ruang Eropah (Nordregio, 2003, Brunet, 1989, dan Nijkamp, 1993, dalam Metaxas dan Tsavdaridou, 2013). Pelajaran yang dapat diambil dari pengembangan blue banana ini ialah pentingnya kesepakatan yang disertai dengan kepastian politik guna menjamin koordinasi dan integrasi pembangunan kota-kota secara lintas negara.

Pelajaran yang dapat diambil dari konsep struktur ruang lintas negara blue banana ini ialah adanya pemikiran terus-menerus dari para akademisi untuk menciptakan suatu benua yang berdaya saing dengan mengembangkan fungsi-fungsi spesifik. Konsep ini bergeser pasca reunifikasi Jerman dengan istilah house with seven apartments. Terdapat istilah sun zone sebagai simbol bagi pusat-pusat kota dengan daya tarik utama pariwisata, ada istilah banana axis untuk menunjukan kawasan-kawasan perkotaan di pusat Eropah barat dengan fungsi industri dan teknologi, serta memberikan peluang bagi wilayah bekas Jerman Timur untuk menjadi pusat pertumbuhan. Lima belas tahun kemudian, tertunjukan bahwa wilayah bekas 
Jerman timur lebih dikembangkan menjadi pusat industri, riset, teknologi dan budaya (Berlin, Budapest, Warsawa, dan Vienna).

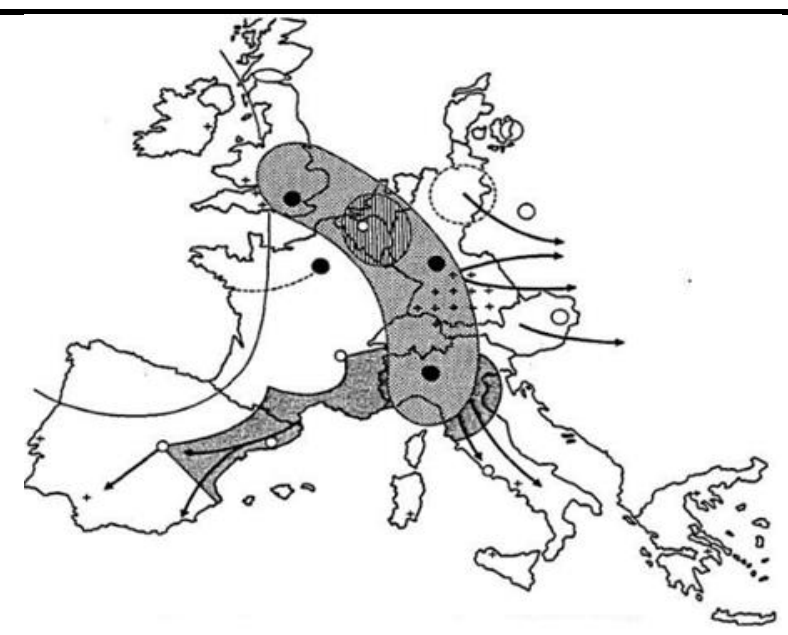

Sumber: Nordregio, 2003, brunet, 1989, dan Nijkamp, 1993, dalam Metaxas \& Tsavdaridou, 2013

\section{Gambar 1. Konsep Blue Banana}

Pada tahun 1990 terdapat penyempurnaan atas konsep blue banana oleh Kunzmann dan Wegener (Kunzmann dan Wegener, dalam Metaxas \& Tsavdaridou, 2013) dengan nama European Bunch of Grapes yang memformulasikan berbagai kluster pembangunan (kecil dan besar) yang belum terakomodasikan melalui konsep blue banana dalam rangka pengembangan kota-kota di Eropah secara lebih berjejaring. Kemudian konsep ini berganti nama menjadi Green Grape karena memiliki tujuan yang lebih luas guna menjamin pertumbuhan kawasan-kawasan di Eropah dimanapun kawasan tersebut berada, supaya lebih berdaya saing di era perkembangan teknologi. Sementara itu, di tengah berkembangnya konsep tentang kota dunia, terdapat fenomena perkembangan kota-kota di Mediterania seperti Barcelona, Madrid, Athena, Lisbon, Torino, dan lainnya di Eropah selatan yang memiliki citra sebagai pusat-pusat ekonomi, dimana dengan dukungan berbagai organisasi dapat menyelenggarakan mega event sekelas Olympic Games tahun 1992 di Barcelona dan Lisbon, serta EXPO di tahun 1998.

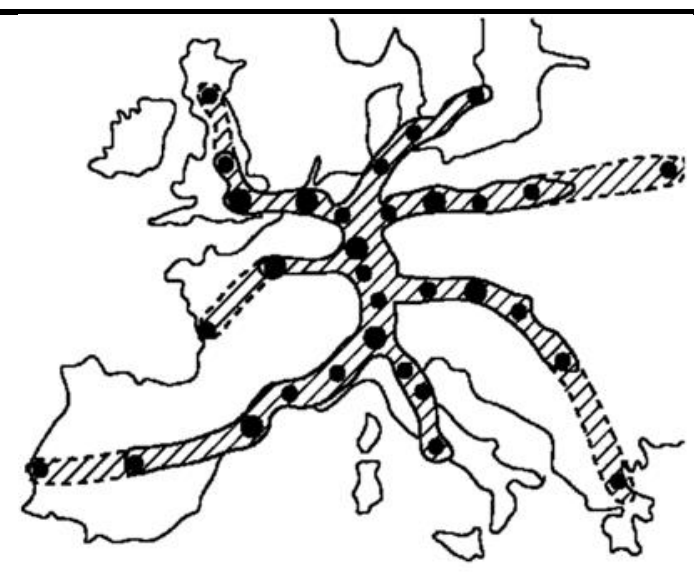

Sumber: Van den Meer, 1998, dalam Metaxas \& Tsavdaridou, 2013

Gambar 2. Konsep Red Octopus 
Metaxas dan Tsavdaridou menjelaskan perkembangan pesat dari konsep struktur ruang di Eropah sampai dengan tahun 1990an yang menyebar dari wilayah barat sampai ke timur Eropah, sehingga memetakan suatu Eropah baru dengan kota-kota yang saling terhubung dan tumbuh dengan nuansa ekonomi dan budaya pada pusat-pusat kotanya. Bentuk baru dari konsep struktur ruang tersebut kemudian diistilahkan oleh van der Meer sebagai red octopus. Pelajaran dari kemunculan red octopus ini ialah pemikiran tentang konsep struktur ruang kota lintas negara tersebut tidak hanya konsep yang dikembangkan oleh para akademisi melainkan pula adanya proses formulasi strategi politik dan prosedur pengambilan keputusan. Red octopus ini memiliki makna tentang pembangunan yang terhubung antar satu kota bahkan negara dengan kota dan negara lainnya, dimana pusatpusat pertumbuhan tersebut merupakan pula pusat investasi bagi riset dan pengembangan teknologi bagi terciptanya kekokohan ekonomi finansial pada skala lintas negara.

Pada akhirnya, di tahun 1999, Komisi Eropah pada pertemuannya di Postdam menetapkan adanya European Spatial Development Perspective (ESDP) dalam rangka menciptakan pembangunan ruang berkelanjutan di Eropah. Hal inilah yang turut menunjang perkembangan konsep kota polisentrik bagi konteks Eropah dalam menciptakan suatu pembangunan berkelanjutan yang berimbang antar pusat pertumbuhan di negaranegara yang berbeda pada satu benua. Selain itu, upaya ini menunjukan kemajuan karena adanya Interreg yang mendorong kerjasama dengan adanya pendanaan dari European Regional Development Fund, dan kemudian terdapat standardisasi Eropah melalui Single European Act (2014-2020).

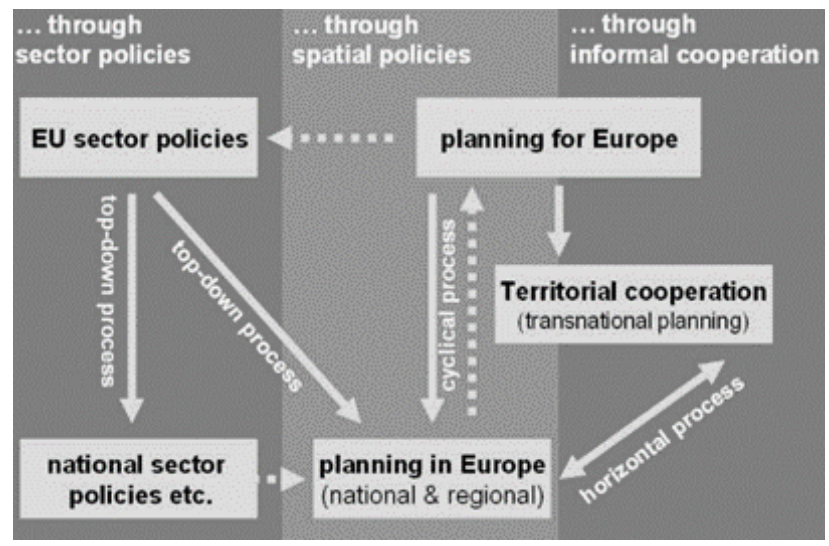

Sumber: Bohme dan Waterhout, 2007, dalam Bohme, 2007

\section{Gambar 3. Europeanization of Planning}

Fenomena inilah yang membuat struktur ruang Eropah menjadi beda dengan yang lainnya seperti diungkapkan oleh Kai Bohme dalam tulisannya yang berjudul European Spatial Policy Making pada COMMIN The Baltic Spatial Conceptshare (Bohme, 2007). Tetapi di lain sisi, ia menjelaskan setidaknya terdapat tiga kesepakatan kebijakan yang memiliki dinamika tersendiri atas konsep struktur ruang lintas negara tersebut, yaitu adanya Common Agricultural Policy (CAP), Structural Funds, dan European Transport Policies. Ketiga hal ini memberikan kejelasan tentang dasar pentingnya dalam pertumbuhan serta perkembangan struktur ruang kota lintas negara (tidak terbatas pada fenomena struktur ruang polisentrik pada satu hamparan) suatu kesamaan pandangan dalam kolaborasi struktur ruang kota antar wilayah (inter region), dimana bentuk nyata dari kolaborasi tersebut berhubungan dengan aksi di bidang ketangguhan kota (direpresentasikan oleh kebijakan pertanian), pembiayaan yang menjadi kunci pembangunan infrastruktur yang menjadi tulang punggung struktur ruang lintas negara, serta kebijakan transportasi lintas negara itu 
sendiri. Inilah pentingnya pembelajaran dari perkembangan struktur ruang multi pusat ataupun polisentrik lintas negara di Eropah yang dapat dijadikan sebagai tantangan bagi pengembangan struktur ruang kota di Indonesia.

\section{Menuju Penataan Ruang Berbasis Pengetahuan}

Bila fenomena tentang pengalaman bagaimana negara-negara di Eropah selama bertahun-tahun membangun kesepahaman akan struktur ruang kota lintas negara, sampai pada akhirnya di tahun 1999 berhasil menelurkan European Spatial Development Perspective (ESDP) ingin dikembangkan di Indonesia, maka penting pula untuk menelusuri tulisan lain yang memungkinkan hal tersebut berpeluang untuk diadaptasi. Secara kronologis, pada masa yang hampir sama, yaitu menjelang era tahun 2000an, seorang akademisi bernama Manuel Castels menulis buku trilogi dengan judul the Rise of the Network Society (Castells, 2010d) ; buku keduanya berjudul the Power of Identity (Castells, 2010c); serta buku ketiganya berjudul the End of Millennium (Castells, 2010a). Pada dasarnya ketiga buku tersebut menjelaskan informasi menjadi penting dalam konteks penataan ruang kota, supaya kota dapat saling berinteraksi antara satu dengan lainnya dengan fungsi yang dimiliki, bagaimana kota supaya memiliki identitas, dan jejaring antar kota tidak hanya terjadi pada satu hamparan, melainkan dapat terjadi pada kota-kota lintas negara di dunia. Hal ini menggambarkan bahwa ada suatu nuansa baru dalam menciptakan keterhubungan antar kota, yaitu adanya informasi dan komunikasi antar warga kotanya yang dapat menunjukan tidak hanya potensi melainkan pula persoalan masing-masing kota, kota tidak hanya semata berhubungan dengan pertumbuhan dan perkembangan aktivitas ekonomi melainkan pula akan memberikan dampak terhadap pola kehidupan sosial masyarakatnya pada tataran global. Ini memberikan makna yang berbeda terhadap pembahasan struktur ruang kota yang pada era setelah tahun 1960an lebih menekankan kepada analisis ekonomi (fungsi kepadatan).

Sementara itu, pada era berikutnya (2010an), fenomena tentang warna struktur ruang kota kian berkembang. Riset terhadap kota-kota di Amerika Serikat dan Kanada sebagaimana diungkapkan oleh Todd Gabe seorang ekonom (Gabe, Abel, Ross, \& Stolarick, 2012) yang memiliki perhatian atas kota menunjukan bahwa identitas dari suatu kota dicirikan oleh adanya nilai-nilai pengetahuan yang kemudian dijabarkan ke dalam tema pusat-pusat kota seperti ragam pusat manufacturing, pusat seni, humaniora, pusat teknologi informasi, serta pusat komersial. Hasil studinya ini menunjukan bahwa kota akan makin berdaya saing dari sisi pendapatan warganya bila menaruh perhatian atas pengembangan nilai-nilai pengetahuan seperti rekayasa (engineering), pembangunan (building), kewirausahaan (enterprising), serta cara membuat (making) dalam konteks pembangunan kota.

Hampir bersamaan dengan studi Todd Gabe, peneliti lain, yaitu Riccardo Cappellin, seorang pengajar manajemen dan hukum di University of Rome Tor Vergata membahas leibh jauh tentang transformasi kota menuju kota bernuansa pengetahuan (Cappellin, 2007). Ia menyatakan bahwa kota dapat dijadikan sebagai suatu barometer ekonomi berbasis pengetahuan, keuntungan kompetitif dari suatu kota berikut wilayahnya ditentukan oleh seberapa besar kota tersebut dapat menerima inovasi. Pada era disrupsi setelah 2010an, sudah selayaknya para perencana mempertimbangkan adanya hubungan timbal balik antara struktur ruang berikut perubahannya dengan fenomena ekonomi berbasis pengetahuan, hal ini dikarenakan struktur ruang dapat berubah ataupun bertransformasi seiring dengan perkembangan pengetahuan dan inovasinya. Era information society ini dapat dicirikan dengan adanya: Kemudian akses informasi; makin beragamnya gaya interaksi; dan rendahnya biaya untuk baik untuk melakukan interaksi maupun mengakses/mendapatkan informasi tersebut.

Di sisi lain Cappellin menjelaskan bahwa pengetahuan merupakan sumberdaya dasar baik dari sisi ekonomi, sehingga pembelajaran merupakan suatu proses yang harus dilalui 
dan dilakukan oleh para pemangku kepentingan, sehingga pada perkembangan berikutnya, Cappellin lebih cenderung untuk menggunakan istilah learning economy dibandingkan dengan knowledge-based economy. Hal ini disebabkan karena terdapat proses pembelajaran di dalamnya, juga pembelajaran tersebut dapat dipelajari pada suatu kawasan tertentu.

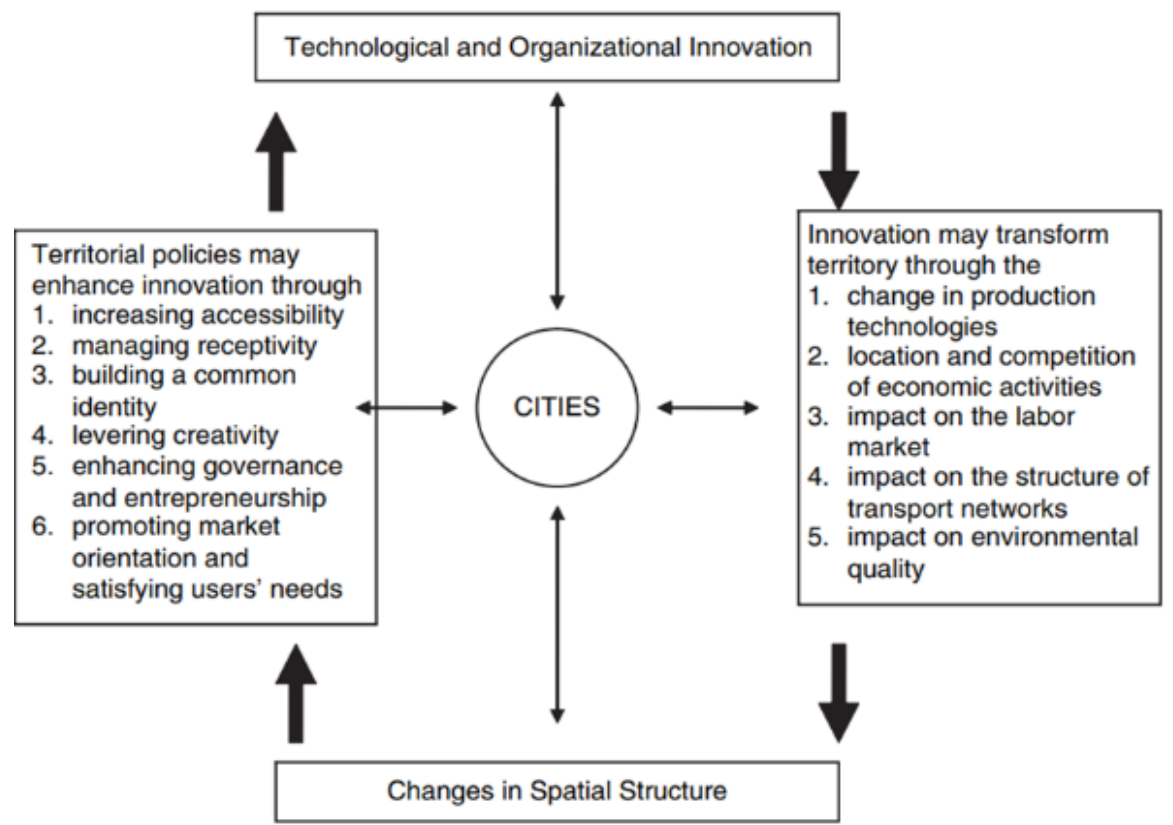

Sumber: Cappellin, 2007

\section{Gambar 4. Inovasi dan Struktur Ruang}

Cappellin menjabarkan bahwa dalam proses perubahan struktur ruang yang dipengaruhi oleh inovasi (baik yang bersifat teknologi maupun keorganisasian/tata kelola), terdapat dua faktor utama yang sangat menentukan. Pertama ialah terkait dengan kebijakan kawasan atau wilayah sebagai upaya untuk meningkatkan inovasi. Adapun peningkatan inovasi tersebut dapat dilakukan dengan beberapa cara, seperti: meningkatkan aksesibilitas, mengelola daya terima atas inovasi, membangun identitas umum, berupaya senantiasa meningkatkan kreativitas, meningkatkan tata kelola dan kewirausahaan, serta mendorong orientasi pasar dan kepuasan dari penggunanya. Sementara itu, faktor keduanya ialah berkaitan dengan kawasan atau wilayah yang direncan, khususnya terkait dengan: perubahan dalam teknologi produksi, lokasi dan daya saing dari aktivitas-aktivitas ekonomi, dampak dari pembangunan terhadap pasar tenaga kerja, dampak dari struktur ruang tersebut terhadap jaringan transportasi, dan terakhir ialah berhubungan dengan dampak atas kualitas lingkungan yang penting untuk diperhitungkan ketika suatu inovasi akan diterapkan.

Dikaitkan dengan uraian teori polisentrik yang diuraikan sebelumnya, Cappellin menerangkan tentang fenomena knowledge creation, atau kreasi pengetahuan yang keberadaan dan pengembangannya tidak dapat dipisahkan dengan spesialisasi sektoral, budaya industri, serta memahami bagaimana sistem inovasi dari kondisi eksisting. Hubungan antar pengetahuan dan representasi ruang ini sangatlah penting pada tahapan identifikasi awal untuk memahami pola baru, membandingkan antara ide eksisting dengan pemanfaatan informasi berikut pengetahuan sebagai tanggapannya. Kendala lainnya dalam melakukan inisiasinya ialah dalam hal konsistensi dan kompatibilitas terhadap solusi eksisting. Faktor-faktor lainnya yang penting untuk dipertimbangkan ialah tentang sejarah setempat berikut peninggalan-peninggalan sejarahnya yang kemudian terpatri pada ingatan 
warga sebagai aktor-aktor lokal. Pada konteks yang lebih luas, sejarah dan peninggalan tersebut dapat dijadikan sebagai bahan bagi alur sejarah secara umum berikut budayanya, sehingga pola dan visi bersama untuk masa depan dapat dirumuskan melalui suatu pemikiran ke depan melalui sifat saling percaya sebagai modal sosial. Literatur Cappellin inilah yang semestinya dijadikan sebagai pembelajaran bagi inovasi wilayah dan kota untuk konteks Indonesia dalam menginisiasi bentuk terobosan-terobosan perencanaan di era disruptif.

Cappellin menjelaskan bahwa klaster geografis atau sistem produksi lokal dicirikan dengan adanya konsepsi umum berikut pendalaman karakteristik pengetahuan guna memberikan proses pembelajaran bagi berbagai perusahaan pada klaster tersebut dalam melihat sesuatu fenomena (guna mendapatkan manfaat) dari perspektif yang berbeda. Pada proses inilah tertunjukan pentingnya keilmuan perencanaan khususnya dalam mendalami karakteristik spasial lokal yang pada gilirannya akan memungkinkan pergerakan atau sirkulasi yang cepat dari pengetahuan dan inovasi.

Cappellin menyimpulkan dari para penulis lainnya bahwa pada proses konsep ini terdapat istilah sistem produksi lokal, yaitu tempat proses pembelajaran interaktif secara kolektif terjadi di mana di dalamnya terdapat keragaman kemampuan yang dapat saling diintegrasikan, sehingga dengan cara ini sisi ketidakpastian dan opertunistik dapat dikurangi guna membentuk suatu sistem ekonomi menyeluruh. Tahap selanjutnya, tedapat penjabaran atas tentang pentingnya pemahaman jejaring dalam menciptakan pengembangan kawasan berbasis pengetahuan, yaitu:

1. Ecology networks ditandai dengan adanya suatu sistem kompleks yang lebih bersifat adaptif dengan kuatnya interaksi.

2. Community networks yang dikembangkan berdasarkan kepada identitas dan konsep kepemilikan bersama.

3. Strategy networks yang dilandaskan kepada kesepakatan kerjasama antar perusahaan dengan organisasi-organisasi lainnya. Strategy network ini ditunjukan dengan adanya kerjasama strategis yang dibuat oleh sekelompok perusahaan baik kecil maupun besar melalui suatu sistem inovasi regional menuju suatu kepentingan bersama membentuk learning region.

Dalam memformulasikan kawasan berbasis pengetahuan, Cappellin mengusulkan suatu istilah territorial knowledge management (TKM), dimana di dalamnya terdapat proses interaksi dan proses kombinasi. TKM ini dapat dijadikan sebagai suatu masukan untuk pengembangan wilayah melalui konsep struktur ruang berbasis pengetahuan di Indonesia dalam memasuki era disrupsi guna menciptakan wilayah yang inovatif dan berdaya saing. Beberapa faktor pada TKM ini sebagaimana diusulkan oleh Cappellin ini ialah:

1. Focus on customer satisfaction. Adopsi inovasi merupakan hasil dari fokus atas kerangka berbasis pemahaman lokal disertai dengan kejelasan batasan dalam menjawab persoalan spesifik melalui kompetensi keilmuan yang saling melengkapi.

2. Manage accessibility and technological capital. kedekatan geografis dan teknologi tepat guna diperlukan untuk memfasilitasi para aktor dengan perusahaan dengan tanpa melupakan karakter dari persoalan lokal, kebutuhan dan sediaan serta kemampun untuk saling melengkapi (komplementer). Diperlukan pula adanya kreasi atas infrastruktur sampai kepada tataran antar wilayah guna memungkinkan pengorganisasian dari jejaring pengetahuan berikut inovasinya.

3. Manage receptivity and human capital. hal ini dipengaruhi oleh beragamnya aktor, pengetahuan, serta karakteristik lokasi dimana pengetahuan dan inovasi akan dikembangkan. Keragaman kemampuan dari aktor berikut tingkat keterlibatannya pun turut menentukan, termasuk di dalamnya latar belakang budaya, sektor ekonomi yang digelutinya, serta spesialisasi teknologinya. 
4. Build a common identity and improve institutional/organizational proximity. Penting untuk secara bersama berbagi antar aktor dalam hal keterlibatan serta bentuk inovasi melalui perumusan tujuan bersama, model, kepercayaan, serta loyalitas.

5. Lever creativity and manage internal organizational capital. Kreativitas sangat terkait dengan perumusan pola atau kemampun dalam menjalin kontak antar berbagai informasi, teknologi, dan keahlian yang saling melengkapi guna mengarah kepada suatu penemuan dan invensi. Makna dari suatu kreativitas ialah menciptakan diversifikasi struktur ekonomi lokal menjadi produk baru, karena kreativitas merupakan suatu kemampuan dalam memberikan solusi secara original.

6. Ensure the governance and enhance entrepreneurship. Persyaratan dari penerapan suatu inovasi ialah adanya kemampuan dalam mendefinisikan persoalan kunci pada konteks lebih luas (organisasi) termasuk pula di dalamnya kemampuan untuk menata hubungan yang kompleks antar aktor dan kemudian melakukan mobilisasi.

Sumber: Cappellin, 2007

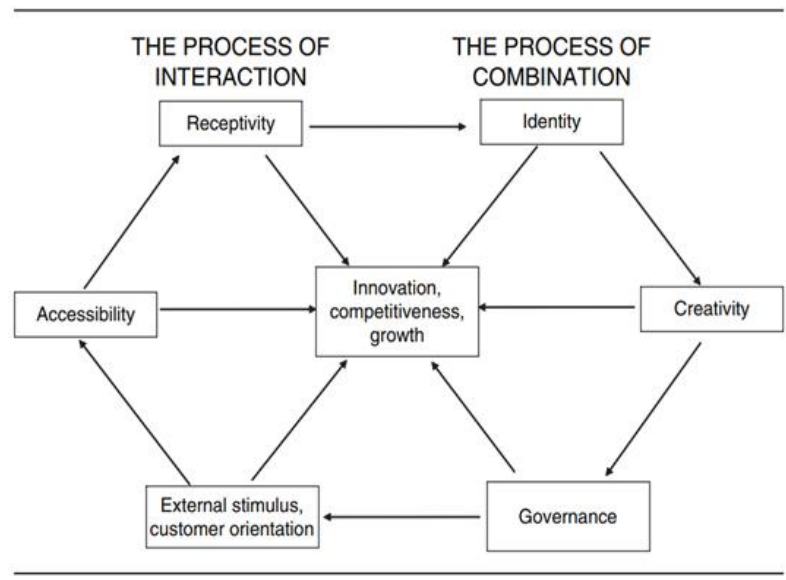

\section{Gambar 5. Inovasi dan Struktur Ruang}

Tidak hanya sampai disini, tetapi karena perencanaan barada pada ranah publik (Friedmann, 1987), maka keenam hal Cappellin tersebut perlu dilengkapi dengan fenomena terkini tentang pentingnya kolaborasi di ranah publik, dimana hal ini pernah disinggung pula oleh Innes dan Booher (2018). Bahwa nuansa kolabarosi pasca tahun 2000an ketika globalisasi, komunikasi instan dan pemanfaatan internet menjadi bagian dari kehidupan sehari-hari yang pada gilirannya akan mendorong terjadinya transformasi kehidupan sosial warganya (Innes \& Booher, 2018). Ditekankan pula bahwa pada era ini ada penguatan peran pemerintah dalam menghadapi tantangan keterbukaan informasi dan menyatukan kesadaran bersama dalam membangun kota yang sinkron dengan penanganan sumberdaya guna menciptakan suatu ketangguhan sistem kota. untuk konteks Eropah, pentingnya kolaborasi, terutama bagi suasana keilmuan dan inovasi seperti dikembangkan oleh Cappellin di atas, telah menjadi tantangan tersendiri dalam menyelesaikan persoalanpersaoalan dasar perkotaan (Sørensen \& Torfing, 2018). Sebagai pembelajaran tentang kolaborasi untuk konteks kota yang dilakukan oleh Sorensen dan Torfing untuk lebih mendorong kolaborasi dari keenam hal yang diusulkan oleh Cappellin di atas, ialah berupa: penjadwalan yang jelas, kejelasan tentang tujuan bersama dari kasus-kasus perkotaan yang akan ditangani, rancangan proyek yang akan dikembangkan, tipe ataupun karakteristik inovasi, penyesuaian/tambahan aktivitas ataupun penggantian, inisiator-inisiator yang terlibat, serta pemicu dari kolaborasi itu sendiri. Peran pemerintah pun perlu disiapkan dalam konteks kolaborasi terkait struktur ruang kota di era disrupsi ini, oleh sebab itu, bila 
dikaitkan dengan hal ini, maka World Economic Forum (WEF) bekerjasama dengan Price waterhouse Cooper (PwC) telah menyusun buku putih Collaboration in Cities: From Sharing to 'Sharing Economy" di mana di dalamnya terdapat rincian peran pemerintah untuk mendorong kolaborasi tersebut (WEF \& PwC, 2017), berikut penekanan peran Pemerintah untuk mendorong kolaborasi pada konteks kota, yaitu Pemerintah sebagai:

1. Regulators. Merekapitulasi aturan eksisting dan mengidentifikasi serta mengarahkan kebijakan baru untuk mendukung situasi yang kondusif.

2. Facilitators/enablers. Mendorong inovasi sosial dain inisiatif lokal dalam konteks bagian dari layanan perkotaan inklusif guna mendorong kolaborasi aktif warga.

3. Integrators/implementers. Menciptakan pasar untuk terlibat aktif dalam berbagai layanan dan sumberdaya.

4. Collaborators. Bermitra dengan para pemangku kepentingan lainnya dalam mengembangkan da mendukung berbagai skema untuk menciptakan tujuan ekonomi positif ataupun dampak lingkungan pada konteks kota. pengembangan mitra tersebut dapat meliputi warga negara, badan public dan otoritas, sektor swasta, masyarakat sipil dan akademisi baik pada tataran lokal/nasional/internasional.

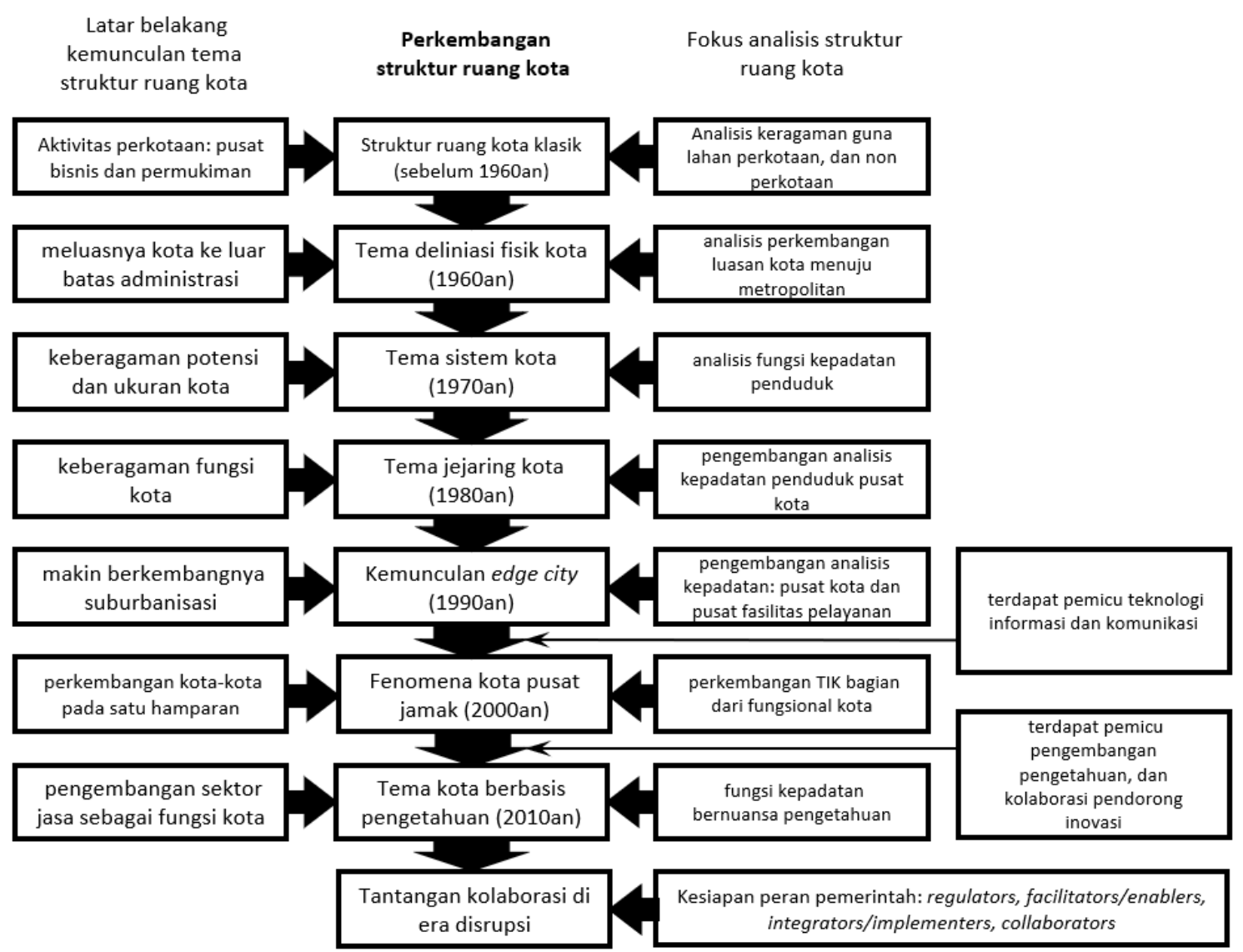

Sumber: Analisis Penulis, 2020

Gambar 6. Perkembangan Struktur Ruang Kota 


\section{KESIMPULAN}

Makin banyaknya penduduk yang tinggal di perkotaan menuntut ada penataan ruang yang lebih baik. Struktur ruang yang secara klasik meliputi moncentric, sectoral, dan multiple nuclei mulai mendapatkan masukan di era 1960an ketika pertumbuhan kota sudah mulai melewati batas administrasi kota. pada dekade berikutnya, studi-studi lebih mengarah kepada fungsi kepadatan atas tingkat keterpusatan kota. keberagaman potensi dan ukuran kota telah menandai analisis fungsi kepadatan penduduk pada perkembangan struktur ruang kota pada 1970an yang lebih menekankan kepada tema sistem kota. Selanjutnya, kebaragaman fungsi kota yang ditandai dengan pengembangan analisis kepadatan penduduk pusat kota telah mengarahkan tema kota di era 1980an ke arah kota yang berjejaring. Makin berkembangnya suburbanisasi di kawasan pinggiran kota utama telah memunculkan tema edge city pada pembahasan struktur ruang kota di era 1990an.

Ketika perkembangan ilmu pengetahuan dan teknologi kian berkembang di era tahun $2000 \mathrm{an}$, struktur ruang kota sudah mengarah kepada pusat kota jamak atau polisentrik yang terus berkembang tidak hanya kepada perkembangan kota-kota pada satu hamparan tetapi juga jejaring kota global. Sebagai kelanjutan dari adanya pemicu yang berupa peran teknologi informasi dan komunikasi setelah era 1990an, dan pengembangan pengetahuan, serta kolaborasi pendorong inovasi di era 2000an, maka kota dengan banyak pusat atau polisentrik di era tahun 2010an telah memiliki nuansa baru dalam perkembangannya, fenomena disrupsi telah mengarhkan munculnya pusat-pusat pertumbuhan bernuansa pengetahuan yang kemudian menjadi tantangan kolaborasi di era disrupsi. Hal ini pun membawa konsekuensi kepada pentingnya kesiapan peran pemerintah untuk menciptakan kolaborasi dalam terciptanya strutkur ruang kota yang inklusif dan berkelanjutan.

\section{PERNYATAAN RESMI}

Artikel ini merupakan pengembangan dari karya tulis Ridwan Sutriadi yang dimuat sebagai pengantar dalam buku Bunga Rampai Studi Perkembangan Pembangunan Kabupaten Subang tahun 2019 di ITB Press.

\section{DAFTAR PUSTAKA}

Albrechts, L. (1998). The Flemish Diamond: precious gem and virgin area. European Planning Studies, 6(4), 411424. https://doi.org/10.1080/09654319808720471

Anderson, B. (1983). Imagined Communities: Reflections on the Origin and Spread of Nationalism. London: Verso.

Bailey, N., \& Turok, I. (2001). Central Scotland as a polycentric urban region: Useful planning concept or chimera? Urban Studies, 38(4), 697-715. https://doi.org/10.1080/00420980120035295

Batten, D. F. (1995). Network cities: creative urban agglomerations for the 21st century. Urban Studies, 32(2), 313-327. https://doi.org/10.1080/00420989550013103

Beatley, T. (2000). Preserving biodiversity challenges for planners. Journal of the American Planning Association, 66(1), 5-20. https://doi.org/10.1080/01944360008976080

Berry, B. J. L., \& Kim, H. (1993). Challenges to the Monocentric Model. Geographical Analysis, 25(1), 1-4. https://doi.org/10.1111/j.1538-4632.1993.tb00275.x

Bohme, K. (2007). European Spatial Policy Making, BSR INTERREG III B project.

Bower, J. L., \& Christensen, C. M. (1995). Disruptive Technologies: Cathing the Wave. HBR, (JanuaryFebruary), 43-53.

Camagni, R. P., \& Salone, C. (1993). Network urban structures in northern Italy: elements for a theoretical framework. Urban Studies, 30(6), 1053-1064. https://doi.org/10.1080/00420989320080941

Cappellin, R. (2007). The territorial dimension of the knowledge economy: Collective learning, spatial changes, and regional and urban policies. American Behavioral Scientist, 50(7), 897-921. https://doi.org/10.1177/0002764206298316

Castells, M. (2010a). End of Millennium (Second). Malden, MA: Wiley-Blackwell.

Castells, M. (2010b). Globalisation, networking, urbanisation: Reflections on the spatial dynamics of the information age. Urban Studies, 47(13), 2737-2745. https://doi.org/10.1177/0042098010377365 
Castells, M. (2010c). The Power of Identity. In The Information Age: Economy, Society and Culture (Vol.2) (Second). https://doi.org/10.2307/2654791

Castells, M. (2010d). The Rise of the Network Society. In The Information Age: Economy, Society, and Culture (Vol.1) (Second). https://doi.org/10.2307/2654643

Champion, A. G. (2001). A changing demographic regime and evolving polycentric urban regions: Consequences for the size, composition and distribution of city populations. Urban Studies, 38(4), 657-677. https://doi.org/10.1080/00420980120035277

Clark, W. A. V., \& Kuijpers-Linde, M. (1994). Commuting in Restructuring Urban Regions. Urban Studies, 31(3), 465-483. https://doi.org/10.1080/00420989420080431

Cowell, M. (2010). Polycentric regions: Comparing complementarity and institutional governance in the San Francisco bay area, the Randstad and Emilia-Romagna. Urban Studies, 47(5), 945-965. https://doi.org/10.1177/0042098009353074

Dieleman, F. M., \& Faludi, A. (1998). Polynucleated metropolitan regions in Northwest Europe: Theme of the special issue. European Planning Studies, 6(4), 365-377. https://doi.org/10.1080/09654319808720468

Friedmann, J. (1987). Planning in the Public Domain: From Knowledge to Action. Princeton University Press.

Friedmann, J., \& Miller, J. (1965). The Urban Field. Journal of the American Institute of Planners, 31(4), 312-320. https://doi.org/10.1080/00049999.1976.9656483

Gabe, T., Abel, J., Ross, A., \& Stolarick, K. (2012). Knowledge in Cities. Urban Studies, 49(6), 1179-1200. https://doi.org/10.1177/0042098011411949

Garreau, J. (1991). Edge Cities: Live on the New Frontier. New York: Doubleday Books.

Giuliano, G. (1998). Information Technology, Work Patterns and Intra-metropolitan Location : A Case Study. Urban Studies, 35(7), 1077-1095.

Giuliano, G., Kang, S., \& Yuan, Q. (2018). Using proxies to describe the metropolitan freight landscape. Urban Studies, 55(6), 1346-1363. https://doi.org/10.1177/0042098017691438

Giuliano, G., \& Small, K. A. (1993). Is the Journey to Work Explained by Urban Structure? Urban Studies, 30(9), 1485-1500. https://doi.org/10.1080/00420989320081461

Harris, C. D., \& Ullman, E. L. (1945). The nature of cities. The Annals of the American Academy of Political and Social Science, 242(1), 7-17. https://doi.org/10.1177/000271624524200103

Harrison Jr, D., \& Kain, J. F. (1974). On Cumulative Urban Growth and Urban Density Functions. Journal of Urban Economics, 1, 61-98. https://doi.org/10.1016/0094-1190(74)90024-2

Heikkila, E. J. (1992). DESCRIBING URBAN STRUCTURE: A Factor Analysis of Los Angeles. Review of Urban \& Regional Development Studies, 4(1), 84-101. https://doi.org/10.1111/j.1467-940X.1992.tb00035.X

Hoyt, H. (1939). The Structure and Growth of Residential Neighbourhoods in American Cities. Washington DC: Federal Housing Administration.

Innes, J. E., \& Booher, D. E. (2018). Planning with Complexity: An Introduction to Collaborative Rationality for Public Policy (Second). https://doi.org/10.4324/9781315147949

Kane, K., Hipp, J. R., \& Kim, J. H. (2018). Los Angeles employment concentration in the 21st century. Urban Studies, 55(4), 844-869. https://doi.org/10.1177/0042098016678341

Kivell, P. (1993). Land and the City: Patterns and Processes of Urban Change. In The Geographical Journal. https://doi.org/10.2307/3059848

Kloosterman, R. C., \& Lambregts, B. (2001). Clustering of economic activities in polycentric urban regions: The case of the Randstad. Urban Studies, 38(4), 717-732. https://doi.org/10.1080/00420980120035303

Kloosterman, R. C., \& Musterd, S. (2001). The polycentric urban region: Towards a research agenda. Urban Studies, 38(4), 623-633. https://doi.org/10.1080/00420980120035259

Kombaitan, B. (1998). Perubahan Struktur Ruang Perkotaan dan Perkembangan Pola Ruang Pergerakan Bekerja: Studi Kasus Kota Bandung dan Sekitarnya. Institut teknologi Bandung.

Lambooy, J. G. (1998). Polynucleation and economic development: the Randstad. European Planning Studies, 6(4), 457-466. https://doi.org/10.1080/09654319808720474

Marcuse, P. (1998). Ghettos and Fortresses, New and Old. In H. Priemus, S. Musterd, \& R. Van Kempen (Eds.), Toward Undivided Cities Cities in Western Europe: New Challenges for Urban Policy, Part 7, Comaparative Analysis (pp. 5-20). Delft: Delft University Press.

Metaxas, T., \& Tsavdaridou, M. (2013). From "Blue Banana" to "Red Octopus" and the development of Eastern and Southern European cities: Warsaw and Lisbon. Regional and Sectoral Economic Studies, 13(1), 15-31.

Mills, E. S. (1970). Urban Density Functions. Urban Studies, 7(1), 5-20. https://doi.org/10.1080/00420987020080011 
Mills, E. S., \& Tan, J. P. (1980). A Comparison of Urban Population Density Functions in Developed and Developing Countries. Urban Studies, 17(3), 313-321. https://doi.org/10.1080/00420988020080621

Musterd, S., \& Van Zelm, I. (2001). Polycentricity, households and the identity of places. Urban Studies, 38(4), 679-696. https://doi.org/10.1080/00420980120035286

Nurfalah, H. (2008). Kajian Karakteristik Pekerja Contingent di Kota Bandung. Studi Kasus Wilayah Pengembangan Ujungberung. Institut Teknologi Bandung.

Nurfalah, H., \& Sutriadi, R. (2009). Information and Communication Technology (ICT) and Metropolitan Area Competitiveness. Indonesian Regional Science Association (IRSA) Conference. Bogor: Institut Pertanian Bogor \& Indonesian Regional Science Association.

Pred, A. (1977). City-systems in advanced economies: Past growth, present processes and future development options. In City-Systems in Advanced Economies: Past Growth, Present Processes and Future Development Options. https://doi.org/10.4324/9781315103136

Priemus, H. (1994). Planning the Randstad: Between Economic Growth and Sustainability. Urban Studies, 31(3), 509-534. https://doi.org/10.1080/00420989420080451

Richardson, H. W. (1988). MONOCENTRIC VS. POLICENTRIC MODELS THE FUTURE OF URBAN ECONOMICS IN REGIONAL SCIENCE. The Annals of Regional Science, 22(2), 1-12.

Sørensen, E., \& Torfing, J. (2018). Co-initiation of Collaborative Innovation in Urban Spaces. Urban Affairs Review, 54(2), 388-418. https://doi.org/10.1177/1078087416651936

Sutriadi, R. (1996). Karakteristik Pemanfaatan Fasilitas Sosial oleh Penduduk Kawasan Pinggiran Kota Bandung. Institut Teknologi Bandung.

Sutriadi, R. (2004). Kajian Literatur tentang Struktur Kota Polisentrik. Bandung.

Sutriadi, R. (2015). Perspektif Perencana tentang Smart City: Inovasi, Kota Komunikatif, dan Kota Berkeadilan. Bandung: Inside Publisher.

Sutriadi, R. (2018). Perspektif Perencana Kota tentang Pariwisata Cerdas. Bandung: ITB Press.

Van Houtum, H., \& Legendijk, A. (2001). Contextualising regional identity and imagination on the construction of polycentric urban regions: The cases of the Ruhr area and the Basque country. Urban Studies, 38(4), 747-767. https://doi.org/10.1080/00420980120035321

World Economic Forum, \& PwC. (2017). Collaboration in Cities: From Sharing to 'Sharing Economy' (No. REF181217). Geneva.

Yigitcanlar, T., \& Inkinen, T. (2019). Geographies of Disruption: Place Making for Innovation in the Age of Knowledge Economy. In Geographies of Disruption. https://doi.org/10.1007/978-3-030-03207-4 